\title{
STUDIES CONCERNING THE HYGIENE CONDITIONS FROM THE SADU FARM, ROMANIA
}

\author{
Mihaela-Adriana, TIŢA ${ }^{1}$, Letiția, OPREAN ${ }^{2}$, Ecaterina, LENGYEL ${ }^{3}$, Ramona Maria, IANCU ${ }^{4}$, Ovidiu, \\ TIȚA $^{5}$, Corina, SIMIAN ${ }^{6}$ \\ „„Lucian Blaga” University of Sibiu, Sibiu, Romaniamihaelaadrianatita@yahoo.com \\ ${ }^{2}$ „Lucian Blaga” University of Sibiu, Sibiu, Romania, letitia.oprean@ulbsibiu.ro \\ „3,Lucian Blaga” University of Sibiu, Sibiu, Romania, ecaterina.lengyel@ulbsibiu.ro \\ ${ }^{4}$ „Lucian Blaga” University of Sibiu, Sibiu, Romania, ramy11us@yahoo.com \\ ${ }^{5}$ „Lucian Blaga” University of Sibiu, Sibiu, Romania, ovidiu.tita@ ulbsibiu.ro \\ ${ }^{6}$ University of Chicago, U.S.A., csimian@cs.uchicago.edu
}

\begin{abstract}
This paper aims to establish the conditions of hygiene of the breeding farm from Sadu, Romania, by monitoring the microbiological indicators such as hospital attendant TNG, total number of yeasts and molds, and total number of coliforms in shelters and on milking equipment. By monitoring air microbial flora, containers used for milking and hygiene of livestock (sheep and cow) values are found by the standards in force, with the recommendation to improve the quality of these parameters in order to reduce the values at lower limits.
\end{abstract}

KEYWORDS: Cow and sheep farm, sanitary indicators, TNG, total coliforms

\section{INTRODUCTION}

One of the basic requirements of food processing industry, is to make available to consumers, food in sufficient quantity and of adequate quality, i.e. with high nutritional value, healthy and pleasurable food (Tita, 2002; Oprean, 2003; Musat et al., 2007).

The milk constituted from the most ancient times an important source of food being consumed both in the natural state as much as under different forms of by-products. Is the most complex and easily assimilated by the organism, constituting one of the basic foods in human nutrition (Oprean et al., 2011).

Through its chemical composition rich and varied, milk provides most of the substances necessary in live tissue construction and maintenance metabolic processes what are going on in the body. Its energy value is 65 - 66 cal per $100 \mathrm{~g}$ (Popa et al., 2014; Te Gifel, 2003; Gilmour et al., 1981; Autunacet al., 2001).

Quality and hygienic condition of the milk will depend on a number of factors link to health state of the animals, hygienic conditions of the milking parlor, hygienic conditions of transport, handling and safekeeping (Iancu et al., 2011; Tita et al., 2011). Under quality report milk must correspond in the first row of its nutritional quality having regard in a daily consumption of children, patients, elderly and even adult. In point of hygiene, milk must be free of any physical nox, chemical, biochemical and microbiological (Oprean et al., 2011; Stan et al., 2011). A problem of contamination on food safety is still a major concern, not only for developing countries, but also for industrialized countries.

\section{MATERIALS AND METHODS}

2.1. Determination of the number of live microorganisms (TNG)

Total number of microorganisms (TNG) is a health indicator and should provide data on the state of contamination of the product or objective examined. This indicator relates only to live microorganisms in the test sample to be checked.

Due to technique commonly applied for the determination of this parameter, it includes only aerobic microorganisms, mostly bacteria. Method for the determination of the total number of microorganisms is based on embedding a certain quantity of the sample in a suitable nutrient medium in Petri dishes in which after incubation at convenient temperatures, of each microorganism will develop a visible colony. Samples were taken from shelters from the animals in the farm and from the air above the milk tank, the method being described by Oprean, 1993.

\subsection{Determination of the number of yeasts and molds}

Yeasts and molds are microorganisms very common in nature. They may be present in some food products on the packaging, in the air, etc. Their presence in large numbers indicate the existence of poor hygiene conditions. Due to their action on food, they can change their organoleptic properties. The wake of development, some of the species may produce toxic products (mycotoxins) very harmful to health consumers. 
Yeasts and molds grow in growing media with acid $\mathrm{pH}$, rich in hidrocarbonate substances at moderate temperatures $\left(18-25^{\circ} \mathrm{C}\right)$, the method being described by Oprean, 1993.

The total number of germs, the number of yeasts and molds is expressed in Colony Forming Units $\left(\mathrm{CFU} / \mathrm{cm}^{3}\right)$.

\subsection{Determining the presence of Coliform bacteria}

By bacteriological analysis of some areas is required determination of an sanitary indicator - Coliform bacteria, which are gram negative (G-) bacills or cocobacilis which grown at $37^{\circ} \mathrm{C}$ in suitable environments, ferments lactose with the production of gas. Group of coliforms shall include in particular species of genera Escherichia, Enterobacter, Klebsiella. They represent a sanitary indicator with a higher meaning, which show on the one hand the implementation conditions and handling of the products, and on the other hand efficient heat treatment which apply to these. For this purpose shall be used culture media containing lactose and inhibitory substances for the flor a with which this lives (Oprean, 1993).

\subsection{The principle of the method}

The presence of coliforms brings out by test of presumption (preliminary examination) and confirmed by the confirmation test (final exam). Presence of coliforms indicate the possibility of a faecal contamination and constitute an alarm signal.

\subsection{Culture media}

Double strength Lauryl sulfate broth, Lauryl sulfate broth simply concentrated, Medium GEAM (gelose-lactose-eosinmethylene blue)

\subsection{Test of presumption (preliminary examination)}

- $10 \mathrm{~cm}^{3}$ samples in 5 test tubes containing $10 \mathrm{~cm}^{3}$ double strength Lauryl sulfate broth

$-1 \mathrm{~cm}^{3}$ sample in 5 test tubes containing $10 \mathrm{~cm}^{3}$ Lauryl sulfate broth simply concentrated

$-10^{-1} \mathrm{~cm}^{3}$ sample in 5 test tubes containing $10 \mathrm{~cm}^{3}$ Lauryl sulfate broth simply concentrated Vials and test tubes sown are entered in the thermostat at a temperature of $37^{0} \pm 0.5^{\circ} \mathrm{C}$, for $48 \mathrm{~h}$. After $24 \mathrm{~h}$ is made a first reading and tolls on GEAM medium for the confirmation test of vials and test tubes where it is found that turbidity and gas. Are considered positive vials and test tubes that highlights fermentation of lactose by the presence of gas in the fermentation tubes, however small quantity of gas generated in the measuring cylinder. Still the tubes shall be maintained in the thermostat up to $48 \mathrm{~h}$. After $48 \mathrm{~h}$ are performed the final reading and transition for the confirmation test for vials and test tubes in which production took a microbial development (turbidity) with or without gas, with the exception of those that have been confirmed at $24 \mathrm{~h}$.

\subsection{The confirmation test (final exam)}

To specify if the fermentation has been produced of coliforms bacills, from each vial or test tube considered positive to the presumptive test are seeding with previously flamed loop on GEAM medium (VRBG gelose-lactose-eosin-methylene blue). Dispersions are made in grooves in sectors in order to obtain isolated colonies (in a Petri dish is plotted at most 6 sectors marked with seeded samples, in the case of passages of the tube and 4 crossing areas in the case of the vials). The Petri dishes are incubared in the thermostat at a temperature of $37^{0 \pm} 0.5^{0} \mathrm{C}$, for a period of 24 hours. The presence of coliforms is confirmed if they have developed characteristic colonies: flat, blue-violet colour, gloss or metallic ribbed, opaque, metallic gloss in the center of or in a choice of pink with the center blue-violet.

\subsection{Establishment of the aproximative number of Coliform bacteria.}

Determination of the aproximative number of Coliform bacteria at $100 \mathrm{~cm}^{3}$ sample is done using the tables edited by Hoschins, quoted by Musat et al., 2007.

\section{RESULTS AND DISCUSSION}

\subsection{Determining microbial load of the atmosphere from sheds}

Microbial load from sheds consists often of bacteria, yeasts and molds from fodders, but also by specific microflora of the stables.

Figure 1. highlights the aeromicroflora of the milk tank, given the values of about two times higher than the germ of yeasts and molds. In these circumstances it is recommended the regular cleaning of the space where is the milk tank, so that air does not constitute a source of contamination to the milk stored in this. Ensure good air quality in farm animal shelters is important for the health and welfare of their staff, but also for environmental protection near livestock units. The air in the shelters contains a wide variety of different gases, a considerable quantity of dust and microorganisms. Concentrations of most of these contaminants can be near or exceed the amount recommended for the animals housed and staff. The total number of mesophilic bacteria was different in shelters investigated, the values measured are similar to those described in the scientific literature. Recent studies indicate average values of the total number of bacteria in dairy sheds between $1,7 \times 10^{3} \mathrm{CFU} / \mathrm{m}^{3}$ and $8,8 \times 10^{4} \mathrm{CFU} / \mathrm{m}^{3}$ or between $2,82 \times 10^{4} \mathrm{CFU} / \mathrm{m}^{3}$ and $7,76 \times 10^{4}$ $\mathrm{CFU} / \mathrm{m}^{3}$. 


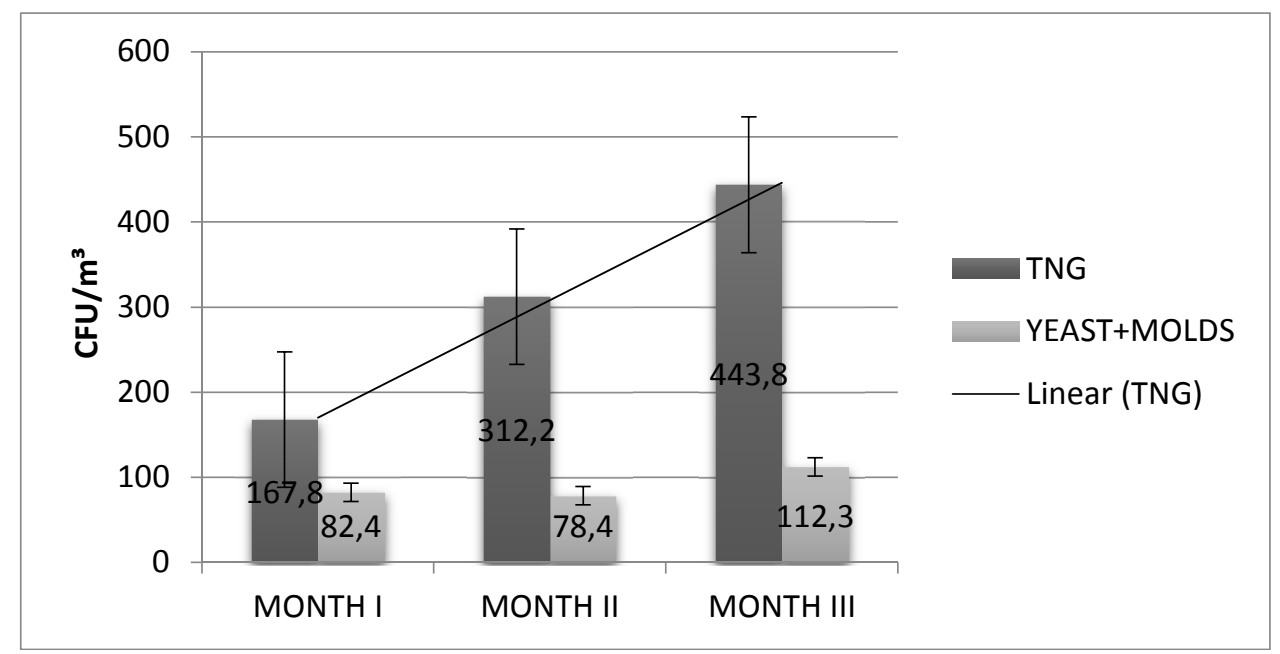

Figure 1. Monthly average of total number of germs, the number of yeasts and molds in milk tank aeromicroflora expressed in $\mathrm{CFU} / \mathrm{m} 3$

Variability in the number of mesophilic bacteria in air shelters is the reason for not yet established a binding international hygienic standard on acceptable number of airborne bacteria. However, most authors recommendation valid in our country is the total number of mesophilic bacteria should not exceed 2,5 $\mathrm{x}$ $10^{5} \mathrm{CFU} / \mathrm{m}^{3}$ in the air of farm's animal shelters. In our study no shelter has exceeded this value. The total number of mesophilic bacteria is the key criteria in assessing the hygienic quality of the air. Microbial load of the air, as indicated by the TNG is influenced by many factors such as the number of animals housed, breeding technologies, such as the floor, the material used as litter, the quality microclimate, the concentration of dust, the level of ventilation, etc. As causes of high levels of air contamination Lange indicated malfunction of ventilation, feed water, the conduct of the work practices and climatic conditions.

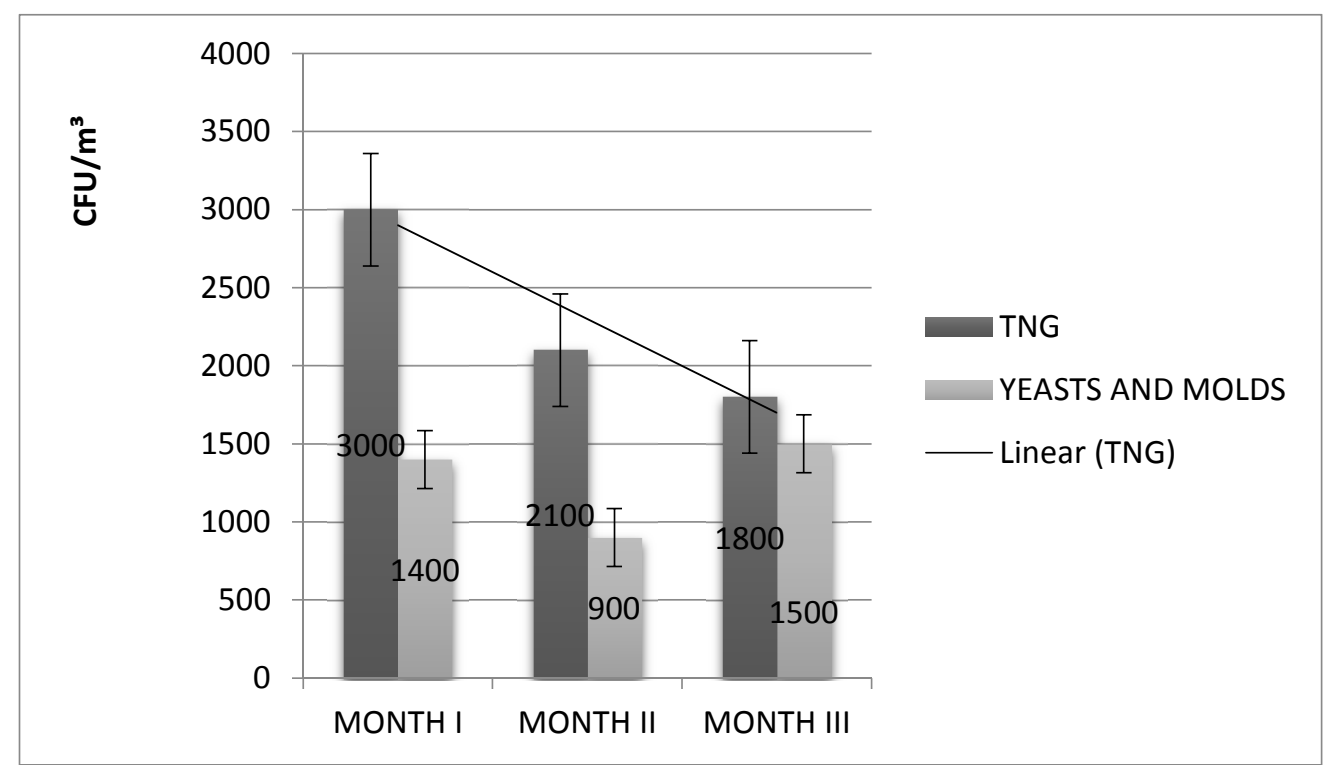

Figure 2. Monthly average of total number of germs, the number of yeasts and molds from aeromicroflora of cow shelter expressed in $\mathrm{CFU} / \mathrm{m} 3$

Following there is a charge results in recommendations of these shelters, reaching maximum values determined at $3 \times 10^{3}$ $\mathrm{CFU} / \mathrm{m}^{3}$ (Figure 2). Because sheep are kept in semi-enclosed shelters are found present aeromicroflora lower by an order of magnitude compared to cow sheds. This is true in that the ventilation is much higher, air currents contributing to their variability.
Following Figure 3 is observed maximum of germs $2 \times 10^{3}$ and minimum $1,6 \times 10^{3} \mathrm{CFU} / \mathrm{m}^{3}$. Yeasts and molds varies between $1,5 \times 10^{2}$ and $2,2 \times 10^{2} \mathrm{CFU} / \mathrm{m}^{3}$, air quality of housing shall be kept by the removal of noxes caused by animals, the manure or feed by permanent ventilation. 


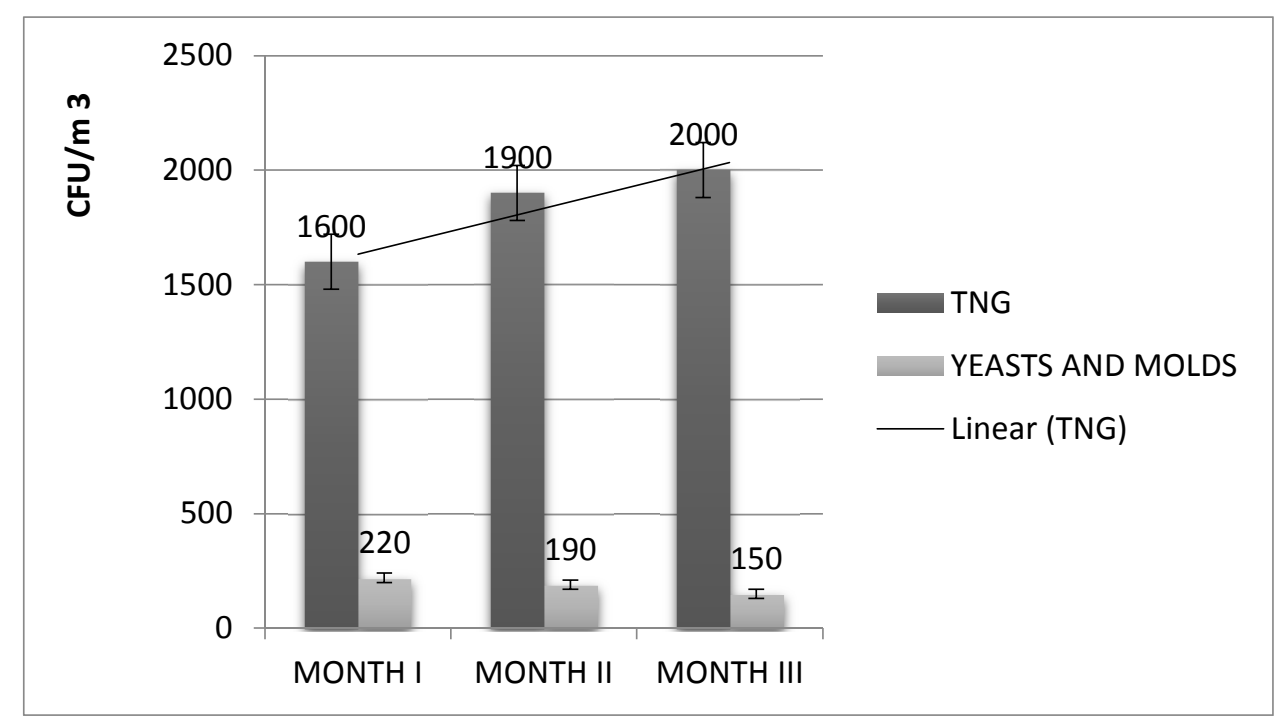

Figure 3. Monthly average of total number of germs, the number of yeasts and molds from sheep shelters aeromicroflora expressed in $\mathrm{CFU} / \mathrm{m}^{3}$

\subsection{Microbiological examination of containers intended for milking and udder}

In a dirty environment, unkempt with dirty animals and cow body resistance against pathogens is diminished aggressiveness. In such cases the diseases incidence is much higher. The most important factor is the stable microflora, that all living organisms, microscopic, invisible to the naked eye, living in the barn. This microflora comes from feed, from faecals, from the ground. These living organisms are called microscopic germs and the number of milk is expressed in total number of bacteria in a milliliter of milk. Some of these microorganisms, particularly those which produce butyric fermentation (rotting), and their sporulated form, inside the milk can not be destroyed at a temperature below $100^{\circ} \mathrm{C}$, end up in the milk products, cheese, where produce fermentation junk.

The milk from cows with diarrhea is very dangerous due to high coliform included and may lead to fermentation. In healthy animals, it was found that the soil particles, feces, crop residues, attached to hair or skin cells from the body of animals can cause a massive increase in the number of microorganisms in milk. Because these organisms do not immediately disperse throughout the mass of milk, is recommended that to filter the milk in clean and tightly sealed milk pots immediately after milking. The contamination grade of milk depends mainly on hygiene measures being taken during milking, the cleanliness of the barn and utensils, hygiene and health condition of the milker.

Figure 4 presents the monthly average of the total number of bacteria, the number of yeasts and molds identified in the canteen for fresh dairy milk collection, expressed in $\mathrm{CFU} / \mathrm{cm}^{2}$ of the three months monitored. Total number of germs determined values are between 136 and $286 \mathrm{CFU} / \mathrm{cm}^{2}$, while yeasts and molds do not exceed $56 \mathrm{CFU} / \mathrm{cm}^{2}$ for cow milk. The value from total number of germs, the number of yeasts and molds identified in the clean canteen for sheep milk collection, are between 45 and $139 \mathrm{CFU} / \mathrm{cm}^{2}$, while yeasts and molds do not exceed 65 $\mathrm{CFU} / \mathrm{cm}^{2}$.

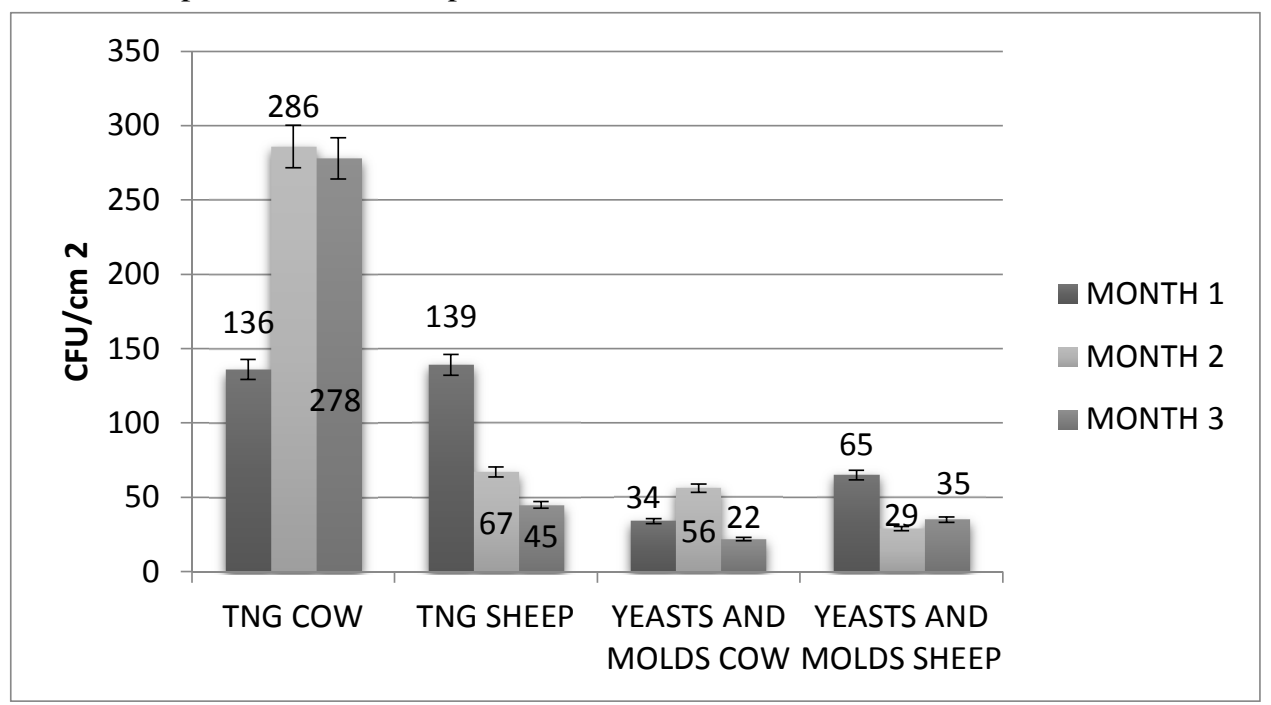

Figure 4. Monthly average of total number of germs, the number of yeasts and molds identified in clean container for the collection of cow's and sheep's milk, expressed in $\mathrm{CFU} / \mathrm{cm}^{2}$ on the three months monitored.

As regards average monthly total coliforms indentified in clean container (Figure5.) for the collection of cow's milk can claim that they provide an upwards trend from the first to the third month. Average values resulting in the first month of the study is at the value of 1,4 , in the month of two to 3,6 and in the month of the third to a value of 5,6. 


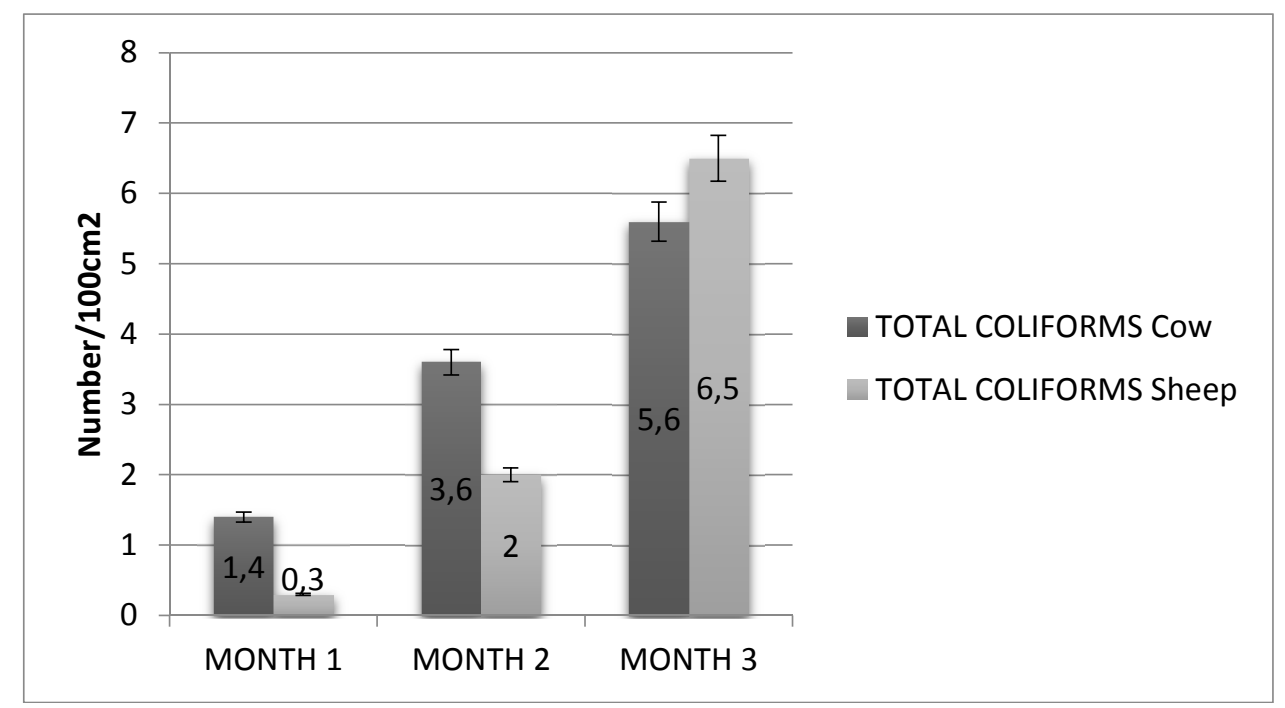

Figure 5. Monthly average of the total coliforms identified in clean container for collection of cow's and sheep's milk, exprimed in number $/ 100 \mathrm{~cm}^{2}$ on the three months monitored

This can be explained by the fact that with the coming heat coliform bacteria are viable, the multiplication being emphasized. To this end cleaning is recommended more responsible for collecting cow's milk canisters. In terms of monthly average of total coliforms identified in clean canister for sheep's milk collection it can be said that they have an upward trend from the first to the second month, then fall to 2 units. Average values in the first month of the study results is around 0,3 in the second month to 2 and in the third the value of 6,5 . It can be said that in the first month the cleaning of the canisters was more responsible so the average dropped three times.

An important indicator of hygiene is the cow's and sheep's udder washing. Figure 6 presents the total number of germs, the total number of yeasts and molds identified after the washing process. It thus appears that $\mathrm{TNG} / \mathrm{cm}^{2}$ varies between 76 and 98 , and yeasts and molds is within a range of $21-42$ units $/ \mathrm{cm}^{2}$ for cow.

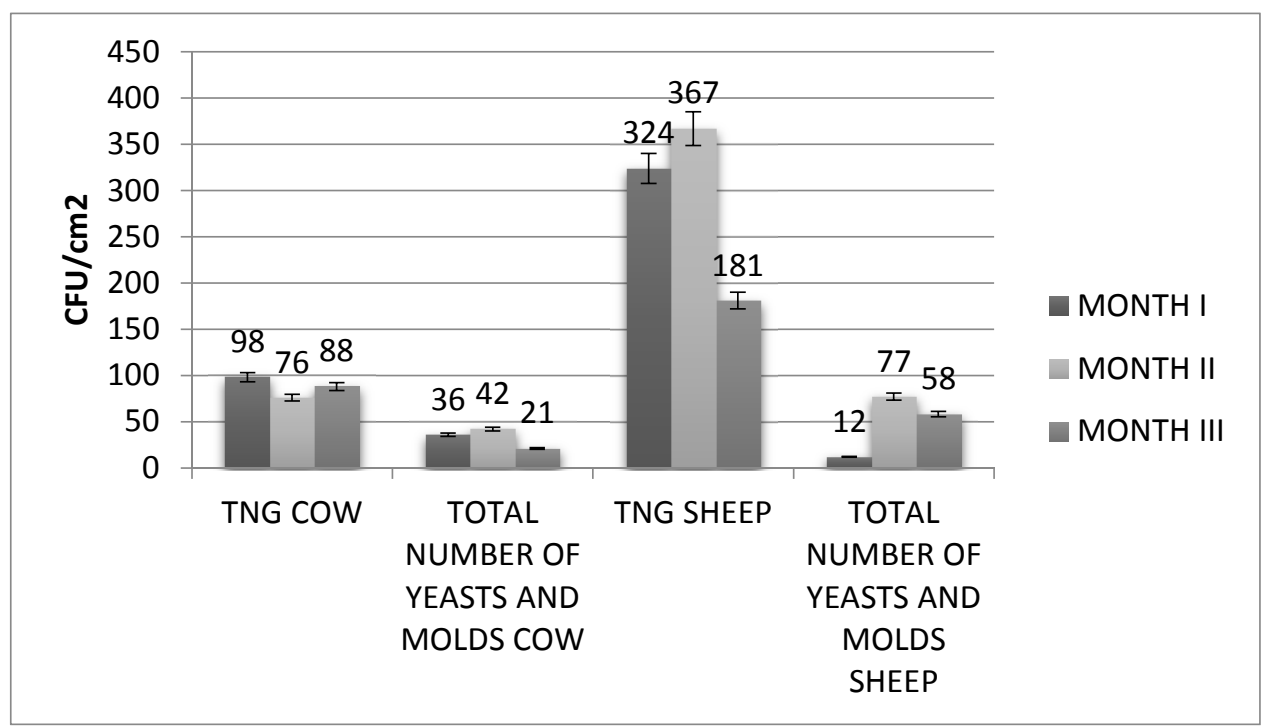

Figure 6. Monthly average of total number of germs, the number of yeasts and molds identified after washing udder of cows and sheeps expressed in $\mathrm{CFU} / \mathrm{cm}^{2}$ on the three months monitored

There was a decrease of $50 \%$ in the third month than in the second month of this indicator. For the sheep TNG varies between 97 and 288 germs $/ \mathrm{cm}^{2}$, and yeasts and molds are located within a range of $29-33$ units $/ \mathrm{cm}^{2}$. It is found a reduction of $10 \%$ in the month of the third compared with month of two of this indicator. From the hygienic point of view this is a breakthrough in the sense that is an acceptable indicator monitored in the legislation In point of hygiene this is a major step forward in the sense that the indicator monitored shall submit acceptable values due to legislation in force.

In terms of total coliforms identified after washing the cow udder (Figure 7) shows the same month the third a $40 \%$ decrease compared to the average of the first two months monitored. In terms of total coliforms identified after washing the udder of the sheep it shows that the average value of the third month, three times lower than the average for the first two months monitored. 


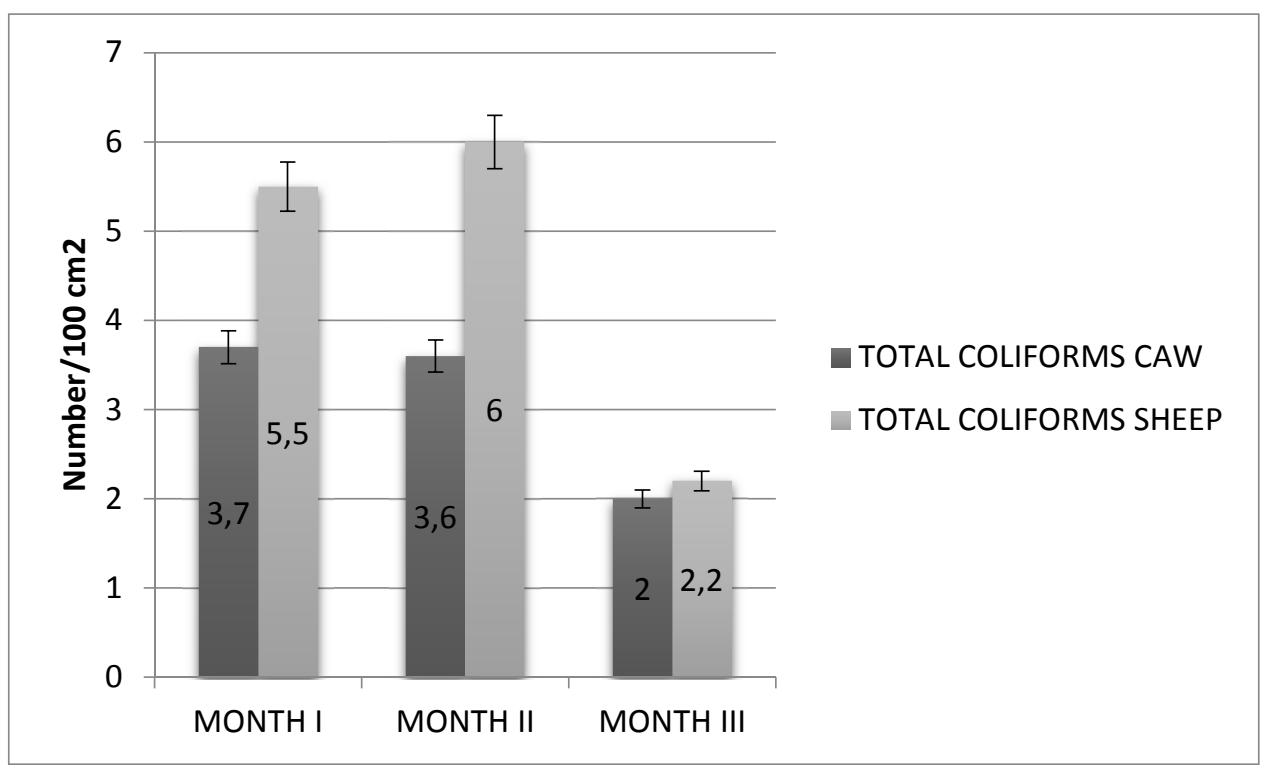

Figure 7. Monthly average of total coliforms identifies after washing the udder of cows and sheeps expressed in number $/ 100 \mathrm{~cm}^{2}$ on the three months monitored

The cooling tank of cow's milk must correspond in point of hygiene and health in such a way that this has been done in the third month of monitoring. The total number of germs does not exceed 56 units and the number of yeasts and molds after washing the cooling tank does not exceed 27 units (Figure 8). The maximum value identified was located in the second month of monitoring where monthly average of the total number of germs was located to a value of $321 \mathrm{UFC} / \mathrm{cm}^{2}$.

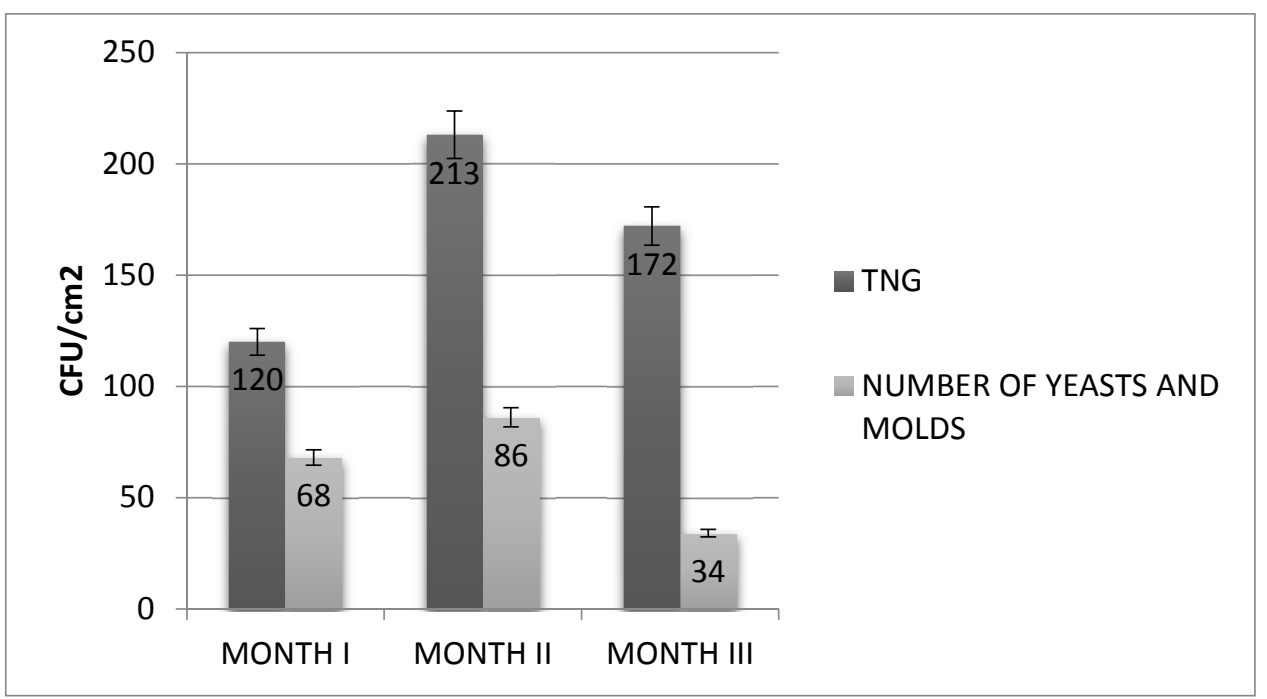

Figure 8. Figure 8. Monthly average of the total number of germs, yeasts and molds identified after washing the cooling cow milk tank, expressed in $\mathrm{CFU} / \mathrm{cm}^{2}$ in the three months monitored

\section{CONCLUSIONS}

The quality and the cleanliness of livestock farms depend on hygienic conditions from the farm.

From the microbiological point of view was found that these conditions are met, but a rigorous control on cleanliness of utensils and staff is required. It is difficult to maintain a perfect hygienic condition in terms of animal shelters, but they can be improved by technologies that lead to improved environmental microbiological characteristics.

It is observed that at a time monitoring variations in the health indicators, these being due to the first term climate since the work is carried out under environmental conditions influence this view.

\section{REFERENCES}

1. ANTUNAC, N., SAMARSIJA, D., HAVRANEK, J.L., PAVIC, V. \& MIOC, B. (2001): Effect of stage and number of lactation on chemical composition of goat milk. Czech.J.Animal Sci. Uzpi (Czech Republic), 46 (12), 548553.

2. GILMOUR, A. \& ROWE, M.T. (1981): Micro-organisms associated with milk. In: Dairy Microbiology. Applied Science Publishers Limited, England, 1(45).

3. IANCU, R., OPREAN, L., TITA, M., LENGYEL, E. \& CODOI, V. (2012): Microbiological Appraisal of Goat Milk under Traditional Management Practices. Proceeding of the International Conference "Agricultural and Food Science, Processes and Technologies" AGRI-FOOD 20, Sibiu, Romania, 352-357.

4. MUŞAT, V., GAŞPAR, E. \& LENGYEL, E. (2007): Igiena intreprinderilor de industrie alimentară şi protecţia mediului, Ed. Univ. „Lucian Blaga”, Sibiu.

5. OPREAN, L. (2003): Microbiologia şi controlul calităţii microbiologice a alimentelor, Ed. Univ. „Lucian Blaga”, Sibiu. 
6. OPREAN, L., IANCU, R., GASPAR, E. \& LENGYEL, E. (2011): Pathogenic microorganisms from raw milk of different animals, Scientific Papers: Animal Science and Biotechnologies, 44 (1), 439-441.

7. OPREAN, L., IANCU, R., GASPAR, E. \& LENGYEL, E. (2011): Pathogenic microorganisms from raw milk of different animals, Scientific Papers: Animal Science and Biotechnologies, 44 (1), 439-441.

8. OPREAN, L., IANCU, R., STAN, R. \& TRASCA, C. (2011): Comparison between Types of Feeding on Goat Milk Composition, Scientific Papers: Animal Science and Biotechnologies, 44 (1), 76-79.

9. POPA, I. R., MIHAELA TIŢA, LETIŢIA OPREAN, RAMONA IANCU, ECATERINA LENGYEL, ADINA FRUM, (2014) Researches on physico-chemical and microbiological characteristics of sheep and cow milk from Cristian farm, Romania, Acta Universitatis Cibiniensis,
Series E: Food Technology, ISSN 1221-4973, vol.XVIII, (1), 77-86,

10. STAN, R., IANCU, R., TOADER, A., MONAFU, L. \& BOBEICA, M. (2011): The Production of Goat Milk under Organic Requests, Scientific Papers: Animal Science and Biotechnologies, 44 (2), 450-454.

11. TE GIFFEL, M.C. (2003): Good hygiene practice in milk processing, in dairy processing - improving quality. G. Smit, Ed. Woodhead Publishing Limited, Cambridge.

12. TITA, M., KETNEY, O., IANCU, R. \& MUHAMMAD, R. (2011): Evaluation of microbiological and physicochemical quality of raw milk from Sibiu dairy farm province of Romania, Animal Science and Biotechnologies Buletin of University of Agricultural Sciences and Veterinary Medicine Cluj-Napoca, 68(2), 463-468.

13. TIŢA, M. (2002): Manual de analiză şi controlul calităţii în industria laptelui, Ed. Universităţii Lucian Blaga, Sibiu. 